\title{
Critical Analysis of $A q l$ and Brain in the Qur'an and Neuroscience and Its Implications for the Development of Islamic Education
}

\author{
$1^{\text {st }}$ Mohammad Jailani ${ }^{1}, 2^{\text {nd }}$ Suyadi $^{2}, 3^{\text {rd }}$ Rena Latifa $^{3}, 4^{\text {th }}$ Siti Nurul Azkiyah ${ }^{4}$ \\ \{mohammad2007052014@webmail.uad.ac.id ${ }^{1}$, suyadi@fai.uad.ac.id ${ }^{2}$, rena.latifa@uinjkt.ac.id ${ }^{3}$, \\ azkiyah@uinjkt.ac.id $\left.{ }^{4}\right\}$ \\ Ahmad Dahlan University ${ }^{1,2}$, UIN Syarif Hidayatullah Jakarta ${ }^{3,4}$
}

\begin{abstract}
The purpose of this study is to analyze the meaning of nasyiyah in the interpretation of Salman from a neo-science perspective. The development of neuroscience and Islamic education in this modern era is in line with the emergence of new findings, namely research about the meaning (nasyiyah) in the Qur'an which some commentators define as "the crown" (prefrontal cortex). This research data is sourced through literature observations related to scientific journal descriptions as well as scrutiny of references to research works, both manually and digitally, which focus on discussing the meaning of nasyiyah in Surah Al-Alaq verses 15-16. This research is a literature study with a qualitative method. Research results prove that the meaning of nasyiyah is identical to the meaning (forehead). In Salman's interpretation, what is meant by the crown is the brain, especially the prefrontal cortex. From a neuroscience perspective, this section plays an important role in controlling emotions as an alternative and healthy memory in the long term, which affects the pattern of thought. Giving a picture of the minds of people who believe and those who turn away from their god, has broad implications for the development of Islamic education today.
\end{abstract}

Keywords: Nasyiyah, Tafsir Salman, neuroscience, al-Qur'an.

\section{Introduction}

The main problem in this research is that neuroscience has so far been considered a secular science because there is no explicit trace of it in the Qur'an. Therefore, this science is less developed in Islamic education because it does not have formal legitimacy in sources of Islamic law related to scientific studies, namely the Qur'an and Sunnah. According to Suyadi (2012), the true essence of Islamic education is to optimize all of its potential on capabilities, all human potential depends on the brain it has [1]. Neuroscience is also expected to help and facilitate this research which is closely related to the brain [2]. In a study between the brain and the mind are very different functions. Human reason is defined as $A l$-' $^{\prime} a q l$ which means preventing and prohibiting, when it is aimed at human attitudes, namely people restrain and curb their desires in bad deeds. Pasiak (2012), argues that in his book Dalil anfus Al-Qur'an and Embryology, namely verses about the creation of man) says that: ("The most ambiguous part of the human body that still surrounds the human body is the brain because it is the skeleton of the human body. which is used to think between spirit and soul, in the sense that spirit and soul are ambiguous") [3]. 
So far, research on "the concept of reason and brain in the Qur'an and neo-science" has become a topic of discussion for academics and researchers, especially in the world of research, even throughout the world [4]. Researchers found in the research base as pioneered by Muh. Amin Abdullah, Quris Shihab [5]. Among the latest research is continued by Taufiq Pasiak who is better known as the study of the brain and 'aql but closer or with a medical approach [6]. Followed by Suyadi, precisely in 2016 until now, which is closer to or cross-breeding the theory of Islamic Education and Neuroscience [7]. These findings are neatly arranged in the research base, especially researchers who knew at Google Cendika. Departing from the literature review, derivatives of the research emerged that discussed the concept of 'aql and brain in the Qur'an and Neuroscience. As the researcher found with his analysis that has been researched by Kasno in his research "Aql and the Brain in the Study of Neuroscience and Its Implications of Scientific Approaches in Islamic Religious Education", Kasno collaborates on the theory of the concept of 'aql and brain, especially in scientific discourse related to Neuroscience [8]. The implications of his research as a reference in Islamic Education and Neuroscience. However, it has not led to a single point of research on the concept of nasyiyah, concentrating more on science and neoscience. Fu'ad has also studied similar research in his research "Brain and Intellect in Neuroscience Verses." Fu'ad described the results of his research on Neuroscience verses in the Qur'an in general, specifically on counting the number of lafadz about 'aql. and Brain in the Qur'an linked to Neuroscience [9]. However, the specifics are not yet fully mature, the results of which are the results of his research on neuroscience verses from the perspective of the Qur'an. Thus, the two studies that exist in the literature facts above, it is important to do further research, especially those related to the 'aql and brain in the perspective of the Qur'an and Neuroscience. From these two reference themes, the researcher focused on the study of the meaning of nasyiyah in the Qur'an, specifically on Tafsir Salman. This research is a follow-up, especially based on the current research as a novelty in previous research and the future. So the researcher's position with these assumptions, this research is different from previous and relevant research today, which focuses on "The concept of the brain and reason in the Qur'an from the perspective of Neorusains:

The purpose of this study is to analyze an analysis of "The Concept of Mind and Brain in the Qur'an and Neorusains: Analysis of Nasyiyah Concepts in Salman's Tafsir". Looking for data related to verses and meanings related to nasyiyah and their influence on the brain and human life. From this, the researchers developed the results of the study, examples of which were related to the concept of nasyiyah. Conformity with the human crown is a place of thought to find alternatives in a conflict. Where it affects the emotions, concerning the meaning of nasyiyah, it is closer to the crown. Serves as the center of human thought in behaving [10]. Until here the extent to which the crown was owned by humans is very influential in his life. The relevance of Surat al-Alaq with the interpretation of Salman's approach is there any effect on neuroscience. is it true that neuroscience is a new science? need to prove its novelty in science?, of course, all of them must be tested with research [11].

This research is based on the argument that the nasyiyah in Surah Al-Alaq appeared in the 7th century. Along with the revelation of the Qur'an, it has a meaning commensurate with the term brain in neo-science which emerged in the 19th century [12]. This research will prove some of the research findings. With the help of using qualitative methods in the literature review. Sources of data from scientific journals and books of scientific work. Of course, in this case, it is very useful for researchers, to support research results from a neuroscience perspective [13]. 


\section{Methodology}

The research in this article uses a qualitative approach. Data were collected through the library research method (Library Study). In a library, data is obtained through examining related literature in the form of articles, books, documents, as well as observing good works that focus on discussing the concept of Surah Al-Alaq in the interpretation of Salman [14]. The formal object of this research is the concept of mind and brain in the Qur'an and neo-science. While the material object is Salman's interpretation which is enriched by the results of his research with nasyiyah concepts [15].

The data collection technique in this research is full sampling, searching, and retrieving data from national journals, international journals, reference books, scientific works (thesis, and dissertation). As well as online references from google scholars, the tools used are documentation instruments. This means that this research utilizes holistically and universally primary and secondary data sources [16].

The focus of this research is the meaning of nasyiyah in Surah Al-Alaq verses 15-16 from a neuroscience perspective. Based explicitly in the Qur'an with the concept of Salman's interpretation which has implications for Islamic education [17].

\section{Result and Discussion}

Based on the literature review and the applied methodology, the results of the study are as follows.

\subsection{The meaning (nasyiyah) of Salman's tafsir perspective}

Etymologically the word nasyiyah comes from the adjective nasa which means cutting hair. Therefore, the word nasyiyah has the meaning of cutting hair, such as the aqiqah activity of a baby at the age of seven months which later with the development of ma'na knowledge is defined as a skull cavity, or called prefrontal, (the limit of hair growth on the face). while nasyiyah is the limit of hair growth on the front of the head [18]. Scientifically (science) this nasyiyah is pre-frontal, originally interpreted as the hair on the human forehead. The commentators, many interpret the context more closely to sinners who continue to develop science, he discusses this in neuroscience. The connection with the letter Al-Alaq verses 16-16 implies that al-nasyiyah is the center of emotional control that humans have on their behavior. To solve the conflicts faced, so that this nasyiyah is related to neuroscience, in scientific physiology it is known as the pre-frontal cortex, which is the place where humans are highlighted in their lives [19].

According to the scientist, lafadz nasyiyah in the Al-Qur'an interpretation of Salman is defined as "the crown". The function of the crown is almost the same as the "heart" of the commentators, which is generally interpreted as the heart, not the unity of the human organs. It's just a group of organs that work together so that humans can feel what they feel [11]. Focus on the fontanel whose function involves various organs of the human body [20]. In the interpretation of Salman, it is said that other people can touch the head, but cannot hold the rope of death. This means that only Allah Swt knows about our death because the identical crown can be interpreted as the rope of death [21]. Ikhtilaf ulama' in interpreting nasyiyah there are those who interpret it as the head book that is in front. In detail, whoever is taken pre-frontal, 
then that person is immediately cut off and cannot move. That's why this nasyiyah is related to Allah's creation. To know the actions of his servants, as long as it is in the context of the truth in his path [22].

Studying the nasyiyah verse (forehead) is aware and introspective in life, that every human life is supervised by Allah SWT (muroqobah). For Allah Swt it is very easy to pull the crown of a human [23]. The Mufassir said that the crown that humans have will follow the character that is attached to them. If the character used always does good, the crown will automatically be smart. On the other hand, if the crown is often used to do despicable things, then the crown will be stupid [24].

\subsection{Neuroscience and meaning (nasyiyah) in the content of tafsir qs. al-alaq verses 15-16}

The fontanel in neuroscience can be called the brain in other terms aligned with (Frontal Lubus). This means that if the human crown is damaged, it will automatically lose consciousness. So that it can lead to excessive depression or the occurrence of forgetfulness [25].

Human reason is directly proportional to the crown in the Qur'an which is said to be nasyiyah. In the interpretation of Salman, the crown is said to be a unitary organ of the human body. That has a special relationship with the function in thinking. The crown can be said to be the rope of human death, if there is damage to the crown (nasyiyah) it will automatically lose its direction. Loss of consciousness resulting in death. Because it is also related to the heart, it makes the heart not beat in general. This nasyiyah verse, including the verse of Allah Swt. Studying the power of Allah SWT and the depth of Allah's knowledge given to humans, so that humans will always be pious [26].

In Surah Al-Alaq 15-16 the word nasyiyah which means the crown is explained by Allah SWT, will uproot human life through the crown of the word nasyiyah, for those who lie and commit sins, as in the interpretation of Salman the explanation of the Mufassir is described as Abu Jahal [27]. As if in thought in the human brain. Containing negative elements, it will automatically affect the behavior of his personality and life in society. Rosidin categorizes the most important points regarding the concept of the crown in the interpretation of Salman ITB as follows: [28].

a. The crown is the forebrain (prefrontal cortex) as the center of consciousness, both evil and goodwill. In other words, the prefrontal cortex functions as a decision-maker. The prefrontal cortex also plays a dominant role in controlling emotions and maintaining longterm memory.

b. The part of the brain just below the crown is part of the control system or nervous system.

c. Damage to the prefrontal cortex has far-reaching consequences. For example, personality changes; Sexual aberrations are also very likely to occur due to damage to the prefrontal cortex.

d. "Forelock" can also be interpreted as "the rope of death" which is located uncertainly.

The meaning of nasyiyah in Surah Al-Alaq has a meaning in the context of extraordinary health, clearly explaining that pleasure is also removed if the pre-frontal is not present. As it is explained in a story "schizophrenic criminals who cannot be cured by psychological therapy, none other than given surgical lobotomy therapy, but at this time the drugs have been found [29]. The human brain consists of 100 billion nerve cells or neurons. Each neuron has many fibers planted with dendrites and axons. Neurons are connected so that there are 100 trillion connections called synapses. Stimulus in nerves is transmitted electrically in neurons and from neuron to neuron through synapses with the help of chemicals called neurotransmitters. There 
are many neurotransmitters including dopamine, acetylcholine, serotonin, endorphins, and so on. All types of drugs affect dopamine in the VTA, nucleus accumbens, and prefrontal. Therefore, the drug greatly affects the damage to the brain and its functions [30].

\subsection{Brain and neuroscience from the perspective of Salman's interpretation}

According to Iip Farliha (2019), the function of the nervous system to monitor integrates and responds to all information around the human organs. In the process of integrating information, there is a sensory interpretation in humans, in this case, it is closely related to the direction and decisions to be taken. Like skeptic or indecisive in him [31]. Anatomically, the nervous system consists of the central nervous system and the peripheral (peripheral) system. The central nervous system consists of the brain and spinal cord, while the peripheral nerves have two main tasks as sensory nerves, namely carrying impulses to the central nervous system, while the second is motor fibers carrying impulses from the central nervous system to the human senses. The fontanel is also defined as the prefrontal cortex. This part is the most important in the brain, fed by neurotransmitters, namely the communication center between nerve cells with one another [32].

According to Suyadi (2019), in the interpretation of Salman, it is explained that if there is damage to the frontal cortex, then there is damage to the human personality. In broad terms, if humans experience damage to the human left brain. Causes prolonged stress and sadness (pseudo depression), whereas if it occurs in the right brain it will result in mental and mental disorders, resulting in mental illness (pseudopsikopath) [31]. For example, in deviant sexual behavior, the prefrontal cortex is also problematic. This means that it results in a reduced human interest in sex because it results in abnormal sexual behavior [33].

Nasyiyah whose function is the same as the brain is an organ of the human body which is located at the very top of the human body. Being in the human head, in this case, indicates how noble humans are compared to other Allah's creatures. Because the placement of the brain is not close to the excretory organ, it is different from animals, which is close to the excretory organ [34]. The meaning of nasyiyah is also many who say reason, in the form of derivation in terms of language morphology in the Qur'an, it is counted 49 times. The Qur'an explains that intelligent people are those who use the functions of their thoughts and feelings well [35]. According to Quraish Shihab, to direct something that protects or forbids committing sins and mistakes, one must use the word of his mind, in this case, it can be understood that every doing something must be based on his mind and personality [36].

\subsection{The meaning of nasyiyah from the perspective of mufassir al-Qur'an}

The word nasfa' means holding, while nasyiyah means the head or crown. In taking a good or bad attitude the crown will always follow. Referring to the letter al-alaq verses 15-16 in the verse "the crown that lies and is disobedient" is defined as mudhaf and mudhaf ilaih or as a trait, the crown is very closely related to human nature and personality [37]. According to Prof. Keith L Moore, in the scientific miracle of the Qur'an, he argues that "information about knowledge about the brain has been explained throughout history". Humans do not find it in health and medical books except in the Qur'an, which already existed at the time of the Prophet Muhammad's medicine, in the discovery of the function of the prefrontal cortex which is closely related to the human brain [38]. In the findings of the prefrontal cortex research in 1842, which occurred after an American worker was stabbed in the head of the stick. Which affects his behavior, experience loss of consciousness, and good personality. It can be understood that 
neorosain was present in the civilization of science along with the decline of the knowledge of the Qur'an. As explained by the commentator, in the results of research on the prefrontal cortex. In the 7th century, many Muslim scholars have researched the brain in understanding Islamic education [39].

\subsection{Interpretation of the brain of a believer in the Qur'an}

The condition of the believer's brain is described as identical to prayer, the person who prays is sure that his brain will be healthy and calm. Talking about prayer, which cannot be separated from the fiqh of the movement in prayer, one of the conditions for prayer is the prostration movement. If it is related to the letter Al-Alaq verse 19 which reads wasjud wa iqtarib, then the word nasyiyah indicates the location of human consciousness so as not to sin and lie in life. Always do prostration to the creator, approach yourself through prayer, one of which is to make the brain healthier and better [40]. According to medics, the state of the brain in which the prostration position in prayer is described stimulates the muscles to develop well. One of them is useful for pregnant women to prevent breach conditions in babies in childbirth, and is also beneficial for restoring and maintaining the abdominal organs in place [41]. When the believer prostrates, in a position signifies humiliation in the eyes of his god. In Islam, humbling oneself to Allah SWT has something to do with medical health, causing the blood vessels in the brain to receive a lot of oxygen forces. Because the heart is above the head which allows blood to flow maximally into the brain [42].

\subsection{Implications of the meaning of nasyiyah in Islamic education}

According to Suyadi, the difference between the crown and the mind or the crown and the heart in education, until now the solution has not been found [43]. For example, people who can work on exact problems are not necessarily able to work on social problems, on the other hand, children who can and have high grades in mathematics are not necessarily capable and masters in the world of music [44]. Suyadi also gave an example of the direction in Islamic education, it is not recommended to prohibit children from praising their minds too much in Islam, the most important thing is the glory of their heart (akhlakul karimah). Islamic education is more recommended with a heart approach in initiating and implementing behavior and personality [45].

It can be determined in the explanation above, meaning that the crown is very necessary to be used as the main basis for thinking because the crown is in harmony with the heart. Thoughts and feelings will produce a good personality, which is also the example of the Prophet Muhammad. The Prophet was sent by Allah SWT to perfect human character. In human life, of course, direction and education have been created, in Islam, it is called Islamic education which leads to good deeds. It lies in the ability of his mind. Always stepping and making decisions according to the command of his mind, Islamic education functions to influence positive reason. Prioritizing a healthy rational mind prioritizes lust and binds it, in terms of having the very implications of being able to control oneself and a mind that can understand the truth [46].

To actualize common sense in influencing the existing nasyiyah, a good process is needed with Islamic guidance and education. Because Islamic education focuses more on Islamic education providing the concept of intellectual education so that humans can improve and achieve living in the world and the hereafter safely and happily. According to As-Syaibani, it is stated that human nature is influenced by three elements including physical, reason, and 
spiritual, which are the most important elements for human life in the world, in achieving awareness of a healthy mind [47].

As-Syaibani mentioned in detail Islamic education cannot be separated from the development of intellectual education in the body, meaning that the physical potential that exists in humans is not useful if the development of the mind does not function. As well as the balance of the three elements between the body, mind, and spirit, namely the body is healthy and strong, the mind is healthy and intelligent, and the heart is always attached to Allah SWT with full of faith [48].

As realized in the Qur'an Surah Al-Alaq verses 15-16, the meaning of nasyiyah about good character and pure honesty has implications for Islamic education. Very influential on the learning of Islamic religious education, to find out the achievements and abilities of students, it is very helpful for the development of thinking, learning achievement. The knowledge abilities possessed are still under the supervision of educators, with that there are principles related to the learning program, including holistic principles, principles of integrity, and principles of affective, cognitive, and psychometric development [49].

The dynamics of reason in the meaning of nasyiyah there are two reasons: firstly because reason prevents negative actions, secondly, the distinction that distinguishes humans from other Allah's creatures. In this case, it is very close to the meaning of reason itself which is interpreted as being bound or bound, in line with the understanding of hadith science, there is a discussion of the hadith of Abu Bakr about "Arabs are reluctant to pay zakat" [50]. He said if they refused to pay me a piece of rope (iqalan) which they previously tied to the Messenger of Allah, I would have fought them. In this case, the word 'Aqal which means bonding; thread or rope, is also corroborated by the hadith of the Prophet 'Adi ibn Hatim, where he said: "When the verse (QS Al-Baqarah: 187) is revealed, this explanation is easy to understand, meaning that the mind is tied to the concept of Islamic direction or education. Allah SWT is perfect for creating human reason [51].

The meaning of nasyiyah in the concept of Islamic education develops the basic characteristics (fitrah) of a child who from the beginning of his creation was born, to grow and develop properly. Improvement and good thinking as well as the encouragement of regular practice to think correctly and be able to maintain, conditions from various influences so that they can make the right and correct decisions [52]. The development of reason in the concept of interpretation mentions the additional development of many and high levels possessed by humans, development in humans is a natural and continuous process that is given by Allah SWT to all living beings. Parents and educators should succeed in having a positive impact on children and students, paying more attention than farmers to their crops [53]. And that plants are influenced by where they grow, students are also greatly influenced by the environment and guidance from their educators as well as their habits from their families and surroundings [54].

\section{Conclusion}

It turns out that the science of Neorusains in the 19th century was very broad and was already present in Islamic civilization along with the revelation of the Qur'an in the 7th century in the decade of the Prophet Muhammad. From the context of the Qur'an, Surah Al-Alaq verses 15-16 relate to the meaning of nasyiyah. In this study, the focus is on the study of meaning (nasyiyah), in the interpretation approach of Salman interpreted (forelock), it has implications for the discussion of the human crown, which greatly affects the brain so that the brain becomes 
healthy and runs as it should, there is also an influence on the brain. intelligence that will have an impact on the life that is lived in work, so that in the end it determines success and happiness. The crown is also interpreted as the rope of human death, only Allah knows regarding the return of humans to the kholiq, the creator of the universe.

The results of this study have broad implications for the multidisciplinary discourse of Islamic education, especially in the fields of Islamic theology, hermeneutics, and scientifically based interpretation of the Qur'an. The researcher recommends to academics, researchers, practitioners, teachers and formal education institutions, and Islamic boarding schools, to conduct further research to find the concepts and models of Islamic Education relevant to this research. Research on the concept of 'aql and brain and their implications is based on interpretation, all theories related to the verses of the Qur'an to bring Muslims closer to the Qur'an. In addition, research that constructs Ibn Sina's multilevel reasoning approach, because researchers are aware that there are no researchers who lead in the basis of this research.

\section{References}

[1] Suyadi and H. Widodo, "Millennialization Of Islamic Education Based On Neuroscience In The Third Generation University In Yogyakarta Indonesia," QIJIS Qudus Int. J. Islam. Stud., vol. 7, no. 1, pp. 173-202, 2019, doi: DOI : 10.21043/qijis.v7i1.4922.

[2] M. Jailani, Suyadi, and D. Djubaedi, "Menelusuri Jejak Otak dan 'Aql dalam Al-Qur'an Perspektif Neurosains dan Pendidikan Islam di Era Pandemi COVID-19," Tadris J. Pendidik. Islam, vol. 16, no. 1, pp. 1-19, 2021, doi: 10.19105/tjpi.v16i1.4347.

[3] T. Pasiak, Tuhan dalam Otak Manusia, Mewujudkan Kesehatan Spritual Berdasarkan Neurosains. Bandung: Mizan, 2012.

[4] M. Wildan, "The Persecution of Rohingya Muslims and the Path to Democratization in Myanmar," Stud. Islam. Indones. J. Islam. Stud., vol. 28, no. 1, pp. 1-18, 2021.

[5] M. A. Abdullah, "Mendialogkan Nalar Agama dan Sains Modern di Tengah Pandemi Covid-19," Maarif, vol. 15, no. 1, pp. 11-39, 2020, doi: 10.47651/mrf.v15i1.75.

[6] T. Pasiak, Revolusi IQ/EQ/SQ: Menyingkap Rahasia Kecerdasan Berdasarkan Alquran dan Neurosains Mutakhir. Bandung: Mizan, 2008.

[7] Suyadi, Pendidikan Islam dan Neurosains: Menelusuri Jejak Akal dan Otak Dalam Alquran Hingga Pengembangan Neurosains Dalam Pendidikan Islam, Pertama. Jakarta: Kencana, 2020.

[8] S. Kasno, "'Aql dan Otak Dalam Kajian Neurosains dan Implikasinya Pendekatan Saintifik Dalam Pendidikan Islam," Muaddib Stud. Kependidikan dan Keislam., vol. 1, no. 2, pp. 154-177, 2019.

[9] S. Kharisma Noor Latifatul Mahmudah, "Akal Bertingkat Ibnu Sina dan Taksonomi Bloom dalam Pendidikan Islam Perspektif Neurosains,” Edukasi Islam. J. Pendidik. Islam, vol. 5, no. 1, pp. 121-138, 2020.

[10] M. Jailani and Nur kholis, "Kajian Pendekatan Hermeneutika dalam Tafsir Al- Qur ' an," J. Qur'an Hadits Stud., vol. 10, no. 1, pp. 93-120, 2021.

[11] M. A. F. Santoso and Y. Khisbiyah, "Islam-based peace education: Values, program, reflection and implication," Indones. J. Islam Muslim Soc., vol. 11, no. 1, pp. 185-207, 2021, doi: 10.18326/IJIMS.V11I1.185-207.

[12] M. Jailani, S. Suyadi, and M. Muallimah, "Pengembangan Pembelajaran Alquran Hadis dengan Pendekatan Akal Bertingkat Ibnu Sina Di SMK Muhammadiyah 3 Yogyakarta Berbasis Neurosains: Di Masa Pandemi Covid-19," SALAM J. Sos. dan Budaya Syar-i, vol. 8, no. 4, pp. 1051-1066, 2021, doi: 10.15408/sjsbs.v8i4.18995.

[13] M. Jailani, U. Ahmad, D. Yogyakarta, H. Widodo, U. Ahmad, and D. Yogyakarta, "Implementation of the Use of Neuroscience-Based Arabic Learning Media on Students : A Case Study at Vocational High School Muhammadiyah 3 Yogyakarta," vol. 5, no. 2, pp. 267-288, 2021.

[14] W. Darmalaksana, Metode Penelitian Kualitatif Studi Pustaka dan Studi Lapangan, vol. 1, no. 1. 
Bandung: UIN Sunan Gunung Djati Bandung, 2020.

[15] Sugiyono, Metode Penelitian Kuantitatif Kualitatif dan $R \& D$, 1st ed. Bandung: Alfabeta, 2012.

[16] Setyowati, Metode Penelitian Pendidikan dan Pengembangan. Jakarta: Kencana, 2010.

[17] Z. Arifin, "Metodologi Penelitian Pendidikan Education Research Methodology," J. Penelit. Pendidik., vol. 1, no. 2, p. 15, 2018.

[18] Suyadi, "Hybridization of Islamic Education and Neuroscience: Transdisciplinary Studies of 'Aql in the Quran and the Brain in Neuroscience," Din. Ilmu, vol. 19, no. 2, pp. 237-249, 2019, doi: 10.21093/di.v19i2.1601.

[19] Suyadi and Sutrisno, "A genealogycal study of Islamic education science at the faculty of Ilmu Tarbiyah dan Keguruan UIN Sunan Kalijaga," Al-Jami'ah, vol. 56, no. 1, pp. 29-58, 2018, doi: 10.14421/ajis.2018.561.29-58.

[20] Zakiyuddin Baidhawy, "Muhammadiyah dan Spirit Islam Berkemajuan dalam Sinaran Etos Alqur'an," Afkaruna Indones. Interdiscip. J. Islam. Stud., vol. 13, no. 1, 2017, doi: 10.18196/aiijis.2017.0066.17-47.

[21] Z. Syarif, S. A. Mughni, and A. Hannan, "Post-truth and Islamophobia narration in the contemporary Indonesian political constellation," Indones. J. Islam Muslim Soc., vol. 10, no. 2, pp. 199-225, 2020, doi: 10.18326/ijims.v10i2.199-225.

[22] M. Jailani, Wantini, Suyadi, and B. M. R. Bustam, "Meneguhkan Pendekatan Neurolinguistik dalam Pembelajaran : Studi Kasus pada Pembelajaran Bahasa Arab Madrasah Aliyah," Al-Thariqah J. Pendidik. Islam, vol. 6, no. 1, pp. 152-167, 2021.

[23] H. Setiadi, "Worldview, religion, and urban growth: a geopolitical perspective on geography of power and conception of space during Islamization in Java, Indonesia," Indones. J. Islam Muslim Soc., vol. 11, no. 1, pp. 81-113, 2021, doi: 10.18326/IJIMS.V11I1.81-113.

[24] A. Muhid, A. Ridho, A. Yusuf, N. Wahyudi, Z. Ulya, and A. H. Asyhar, "Big Five Personality Test for State Islamic Senior High School Students in Indonesia," Int. J. Instr., vol. 14, no. 2, pp. 483500, 2021.

[25] M. Jailani, Suyadi, and B. M. R. Bustam, "The First HISPISI' s International Conference on Humanities , Education, Law , and Social Sciences 'New Findings during Pandemic in Social Science, Humanities, Education and Law ," in Neuroscience Based Islamic Learning a Critique of the Holistic Education Crisis in Pamekasan Madura, 2021, pp. 123-134.

[26] M. Jailani et al., "Pengembangan Materi Pembelajaran Pendidikan Agama Islam: Implikasinya Terhadap Pendidikan Islam," Al-Idarah J. Kependidikan Islam, vol. 11, no. 1, pp. 143-155, 2021.

[27] Suyadi, Z. Nuryana, and N. A. F. Fauzi, "The fiqh of disaster: The mitigation of Covid-19 in the perspective of Islamic education-neuroscience," Int. J. Disaster Risk Reduct., vol. 51, no. 2, p. 101848, 2020, doi: 10.1016/j.ijdrr.2020.101848.

[28] M. Q. Khairuzzaman, "Tafsir Ilmiah Salman ITB (Telaah Kritis Perspektif Ulum al-Qur"an )," Ulumul qur'an, vol. 4, no. 1, pp. 64-75, 2016.

[29] Iip Farliha, "Tafsir Salman ITB. Bandung," in TAFSIR SALMAN ITB, Bandung: itb, 2019, p. 2010.

[30] Suyadi, Sumaryati, D. Hastuti, D. Yusmaliana, and R. D. R. MZ, "Constitutional Piety: The Integration of Anti-Corruption Education into Islamic Religious Learning Based on Neuroscience," $J$. Pendidik. Agama Islam, vol. 6, no. 1, pp. 38-46, 2019, doi: DOI : 10.18860/jpai.v6i1.8307.

[31] M. Pesenti, M. Thioux, X. Seron, and A. De Volder, "Neuroanatomical substrates of Arabic number processing, numerical comparison and simple addition: A PET study," J. Cogn. Neurosci., vol. 12, no. 4, pp. 461-479, 2021, doi: 10.1016/s1053-8119(18)31064-4.

[32] H. Abadzi, "How to Speed up Arabic Literacy for Lower-Income Students? Some Insights from Cognitive Neuroscience," How to Speed up Arab. Lit. Low. Students?, vol. 1, no. 9, pp. 1-23, 2012, doi: $10.1596 / 26823$.

[33] M. Mohammadipur, "Relationships Between Language Learning Strategis, Positive Emotions, Language Learning Motivation and English Language Proficiency Among Malysian ESL Undergraguates," University Putra Malaysia, 2018. 
[34] S. Boudelaa, F. Pulvermüller, O. Hauk, Y. Shtyrov, and W. Marslen-Wilson, "Arabic morphology in the neural language system," J. Cogn. Neurosci., vol. 22, no. 5, pp. 998-1010, 2010, doi: 10.1162/jocn.2009.21273.

[35] H. Racmawan, "Hermeneutika Alquran Kontekstual: Metode Menafsirkan Alquran Abdullah Saeed," Afkaruna, vol. 9, no. 2, pp. 148-161, 2013, doi: 10.18196/AIIJIS.2013.

[36] A. Razzaq and D. M. Saputra, "Studi Analisis Komparatif Antara Ta'wil dan Hermeneutika dalam Penafsiran al-Qur'an," Wardah, vol. 17, no. 2, pp. 89-114, 2016.

[37] A. R. Muchlisin and K. Nisa, "Geliat Tafsir "Ilmi di Indonesia dari Tafsir Al-Nur hingga Tafsir Salman," Millati J. Islam. Stud. Humanit., vol. 2, no. 2, p. 239, 2017, doi: 10.18326/mlt.v2i2.239-257.

[38] H. Fadilah and Suyadi, "Mirror Neuron in The Perspective Of Islamic Education," Edukasi, vol. 8, no. 2, p. 26, 2020.

[39] M. F. R. Suyadi, "Tafsir Ayat-ayat Neurosains (The' Aql in the Qur'an and its Relevance to the Development of Critical Thinking in Islamic Education)," J. At-Tibyan J. Ilmu Alqur'an dan Tafsir, vol. 5, no. 1, pp. 138-152, 2020, doi: 10.32505/tibyan.

[40] J. C. Kamilah, Metodologi penafsiran kitab Tafsir Salman tafsir ilmiah atas Juz'Amma karya 26 Pakar ITB. Surabaya: UIN Sunan Ampel Surabaya, 2019.

[41] M. H. I. Hafizzullah, Dapit Amril, "Metode Muhammad Al Amin Al Haraari dalam Tafsîr Hadâiq Ar-Rauhi Wa Ar-Raihân," Al Fawatih J. Kaji. Al Quran dan Hadis, vol. 1, no. 1, pp. 62-77, 2020, [Online]. Available: http://194.31.53.129/index.php/fawatih/article/view/2667.

[42] I. H. Hisan, "Ayat-Ayat Kauniyah dalam Juz 30: Studi Komparatif Tafsir Al-Jawahir karya Thanthawi Jauhari dan Tafsir Salman ITB karya Tim Salman ITB.” UIN Sunan Gunung Djati Bandung, p. 10, 2018.

[43] Suyadi, "Pendidikan Islam Inklusi Humanis Dan Religius," Tajdidukasi, vol. VII, no. 2, pp. 1527, 2017.

[44] Y. Desva and Suyadi, "Pengembangan Imajinasi Kreatif Berbasis Neurosains dalam Pembelajaran Keagamaan Islam," Edukasia J. Penelit. Pendidik. Islam, vol. 14, no. 2, p. 267, 2019, doi: 10.21043/edukasia.v14i2.4213.

[45] Asep Saepudin Jahar, "Bureaucratingzing Sharia in Modern Indonesia: The Case of Zakat, Waqf and Family Law," Stud. Islam. Indones. J. Islam. Stud., vol. 26, no. 2, pp. 207-244, 2019.

[46] R. Sari and M. N. I. Saleh, "Readiness to Implement Inclusive Education in Muhammadiyah Elementary Schools of Yogyakarta," Afkaruna Indones. Interdiscip. J. Islam. Stud., vol. 20, no. 2, pp. 263-287, 2020, doi: 10.18196/aiijis.2020.0124.263-287.

[47] B. Bensaid, S. B. T. Machouche, and M. Tekke, "An Islamic Spiritual Alternative to Addiction Treatment and Recovery," Al-Jami'ah, vol. 69, no. 1, pp. 127-162, 2021, doi: 10.14421/ajis.2021.591.127-162.

[48] A. T. Gallop, M. Wildan, and R. Hidayatullah, "The social Integration of Hindu and Muslim Communities: The Practice of 'Menyama-Braya' in Contemporary BAli," Stud. Islam. Indones. J. Islam. Stud., vol. 28, no. 1, 2021.

[49] N. Wendry, S. Sefriyono, and M. Yusuf, "The Map of Jihad Meaning Among Junior High School Students in Padang, Indonesia," ESENSIA J. Ilmu-Ilmu Ushuluddin, vol. 21, no. 2, 2020, doi: 10.14421/esensia.v21i2.2316.

[50] S. N. Hidayah, "Pesantren For Middle-Class Muslims in Indonesia (Between Religious Commodification and Pious Neoliberalisme," Qudus Int. Islam. Stuies, vol. 9, no. 1, pp. 209-244, 2021. [51] Kusmana, "The Qur'an, Woman, And Nationalism In Indonesia Ulama Perempuan's Moral Movement," Al-Jami'ah, vol. 57, no. 1, pp. 83-116, 2019, doi: 10.14421/ajis.2019.571.83-116.

[52] M. Pabbajah, I. Abdullah, H. Jubba, M. Taufiq Hidayat Pabbajah, and Z. Said, "Pilgrimage to bawakaraeng mountain among the Bugis-Makassar in Indonesia: A contestation between islamic identity and local tradition," Int. J. Relig. Tour. Pilgr., vol. 9, no. 1, pp. 178-190, 2021, doi: 10.21427/S3P3-YA23.

[53] M. F. Asep Saepudin Jahar, Amany B. Lubis, "The Use of Maqasid Al-Sharia in Maritime and National Resilience Contex," Al-Risalah Forum Kaji. Huk. dan Sos. Kemasyarakatan, vol. 21, no. 1, 
pp. 97-110, 2021, doi: 10.30631/al-risalah.v21i1.657.

[54] C. Mahfud, R. Astari, A. Kasdi, M. A. Mu'ammar, M. Muyasaroh, and F. Waidi, "Islamic cultural and Arabic linguistic influence on the languages of Nusantara; From lexical borrowing to localized Islamic lifestyles," Wacana, vol. 22, no. 1, pp. 224-248, 2021. 